\title{
The Lincoln Project and the Conservative Aesthetic
}

\author{
Dannagal G. Young ${ }^{1}$ \\ (C) Springer Science+Business Media, LLC, part of Springer Nature 2020
}

\begin{abstract}
This election season, a rogue band of Republican Party operatives has attracted considerable media attention, and the Twitter wrath of President Trump, with a series of negative advertisements attacking the incumbent. The Lincoln Project strategy demonstrates how social and cultural conservatives are attracted to a particular aesthetic, prompted by their psychological attraction to rhetorical forms that are threat-oriented, clear, efficient, hyperbolic, emotional, and authoritative.
\end{abstract}

Keywords Political psychology $\cdot$ Trump $\cdot$ Political advertising

On December 17, 2019, the New York Times published an oped penned by four former Republican strategists and campaign consultants. The piece, "We are Republicans, and we Want Trump Defeated," served as the manifesto for the socalled "Never Trump" movement, and marked the birth of The Lincoln Project $(L P)$, an anti-Trump political action committee, or Super-PAC - that dominated headlines (and angry presidential tweets) throughout the 2020 campaign season. Their stated goal was to "... [persuade] enough disaffected conservatives, Republicans and Republican-leaning independents in swing states and districts to help ensure a victory in the Electoral College..." To do this, the team hired skilled video producers and social media managers to create and disseminate hard-hitting anti-Trump ads at breakneck speed. And as the ads went viral on Facebook and Twitter, and the Lincoln Project received the attention of journalists, scholars, the public, and the President, one set of questions proved unavoidable: Why did it take a team of Republicans to produce these visceral attacks? And why don't Democrats make ads like this? At least part of the answer, I contend, rests in the psychology of political ideology and its connections to rhetorical and aesthetic preferences, preferences that make conservatives more likely to embrace rhetorical forms that are threat-oriented, clear, efficient, hyperbolic, emotional, and authoritative. The success of the Lincoln Project rests in their intimate knowledge of the psychology of conservatism, and in the

Dannagal G. Young

dgyoung@udel.edu

1 University of Delaware Newark, Newark, DE 19716, USA economics and affordances of what LP's Rick Wilson has called "the most meaningful tool of political manipulation ever devised in the history of all mankind: Facebook."

\section{Mourning in America and the Start of a Viral Onslaught}

On May 4, the Lincoln Project released "Mourning in America," an inverted take-off on the classic positive 1984 Ronald Reagan campaign ad, "Morning in America." The Lincoln Project's version was ominous in tone, with dark visual contrasts, featuring body bags and music in a minor key. A frightening voice-over described dire aspects of life under the Trump presidency and warned of worse times to come:

... Today, more than 60,000 Americans have died from a deadly virus Donald Trump ignored. With the economy in shambles, more than 26 million Americans are out of work - the worst economy in decades...This afternoon, millions of Americans will apply for unemployment, and with their savings run out, many are giving up hope. Millions worry that a loved one won't survive COVID-19. There's mourning in America, and under the leadership of Donald Trump, our country is weaker and sicker and poorer. And now, Americans are asking, if we have another four years like this, will there even be an America? 
Within hours, the president had responded directly to the ad on Twitter (See Fig. 1). The Lincoln Project capitalized on the increased donations stemming from news coverage of the "Mourning in America" ad and Trump's Twitter response. In the days that followed, the group raised over $\$ 1$ million, a sum which would reach almost $\$ 20$ million by the end of June.

While most of the Lincoln Project ads are threatening and dark in theme and tone, the team also produced derisive ads aimed at Trump himself. In late June and early July, two such ads were released. One ad, euphemistically entitled "Shrinking," mocked the size of Trump's smaller-thananticipated campaign rally in Tulsa, Oklahoma. "Turnout in Tulsa?" the narrator chides the president, "A dud. You've probably heard this before, but it was smaller than we expected." The second, "Fellow Traveler," featured a Russianaccented narrator describing "Comrade Trump" as having enthusiastically accepted the endorsement of Russian President Vladimir Putin: "Comrade Trump's campaign wisely accepted our help." He "gladly accepted the help of Mother Russia... Congratulations, Comrade Trump!"

As of the writing of this piece, the impact of these ads on public opinion is still unknown. But the impact of the Lincoln Project on the press is clear. All major national newspapers across the United States have published feature stories about the anti-Trump Super-PAC or its founding members. The major broadcast networks have all covered it. The cable news stations have all covered it. The counterintuitive "former GOP politicos try to sink Trump" has a reflexive novelty to it. And the spectacle of the organization is only enhanced by the fact that founding Lincoln Project member George Conway is married to Trump White House counselor Kellyanne Conway. (In August, both Conways decided to step away from politics in order to attend to family matters.)

Creating emotionally evocative political ads and grabbing the press's attention are not new endeavors for members of the LP team. The members' campaign and attack ad experience dates back decades. John Weaver worked on Senator John McCain's 2000 primary campaign, helping to cultivate his "maverick" image and devising McCain's famous bus tour, dubbed the

\section{Donald J. Trump}

@realDonaldTrump

A group of RINO Republicans who failed badly 12 years ago, then again 8 years ago, and then got BADLY beaten by me, a political first timer, 4 years ago, have copied (no imagination) the concept of an ad from Ronald Reagan, "Morning in America", doing everything possible to....

12:46 AM - May 5, 2020 - Twitter for iPhone

24.9K Retweets and comments $\quad \mathbf{8 9 . 2 K}$ Likes

Fig. 1 Trump response to "Mourning in America"
"Straight Talk Express." Strategist Steve Schmidt is a veteran of the 2008 McCain presidential campaign, and rather (infamously and regretfully) encouraged McCain to bring political outsider Sarah Palin onto the GOP ticket. Consultant and author Rick Wilson was the mastermind behind the controversial 2002 attack ad against disabled veteran Democratic Senator Max Cleland from Georgia. That ad, featuring images of Osama Bin Laden and Saddam Hussein, raised questions about Cleland's voting record and patriotism. Cleland lost the election.

\section{"Why don't Democrats do this?"}

As the Lincoln Project continued to produce ads and dominate headlines into the summer, conversations about their resonance and potential impact often centered around one key question: Why did it take this group of Republicans to make these vicious takedowns? Why can't (or why don't) Democrats produce ads like this? Vanity Fair's Caleb Ecarma attributed the success of LP to their "... willingness to get down in the kind of dirt that many Democratic ads won't touch." Quoted in The Nation, iconic Democratic strategist James Carville suggested, "[the Lincoln Project] fights hard. And we don't fight like that...Democrats could learn a lot from them." He went so far as to describe the LP members as "mean." On Twitter, newly posted LP ads are routinely followed by the same incredulous question: "Why can't DEMOCRATS produce timely response videos like this one!?" "These Republicans are making the best campaign ads. Not to look a gift horse in the mouth...but why can't Democrats get it together and make ads like these?"

As weeks passed and the viral ads continued to garner the attention of journalists and pundits, criticism emerged. Liberal writers and activists warned Democrats to be wary of the intentions of these so-called "Never Trumpers." The Washington Post's Greg Sargent wrote,

The Lincoln Project is working to insulate conservatism from blame for Trump so it can rise again. Its condemnations of Trump don't acknowledge the GOP's culpability for creating the conditions for his rise. Allowing the group influence over a Joe Biden presidency will cripple his ability to rescue the country.

Critics argued that LP was aimed at "laundering the reputations of its principals" and "repairing the moral standing of the Republican Party and the conservative movement in general." Such efforts should be met with suspicion and even rejected out of hand, they asserted. Progressive writer Eoin Higgins warned: "The more that liberals refuse to hold right-wing operatives like the Lincoln Project brain trust accountable for their past behavior...the more we will see the rehabilitation of such ghouls as an 
ongoing scheme by conservatives to push the Overton window even further right and assume the position of moderation."

But another set of concerns surfaced as well, not about the GOP operatives' real intentions, but rather the ethics and appeal of their abrasive rhetorical attacks. The Atlantic's Andrew Ferguson described the ads as: "personally abusive, overwrought, pointlessly salacious, and trip-wired with non sequiturs." The New York Post's Rich Lowry urged, "LP [isn't] resisting the coarsened political culture to which Trump has contributed more than his share. No, they are happily embracing it, apparently believing that their spittleflecked rage passes for wit."

In June, LP's Twitter account posted a GIF of President Trump tripping up the steps to Air Force One and captioned it "The Trump Administration's coronavirus response." Columnist Connie Schultz replied, "Mocking a person's physical abilities is such a Trump thing to do. Let's try harder, please." Criticisms of the LP ads as "ableist" became commonplace, especially following the June 16 ad "\#TrumpIsNotWell," which highlighted clips of Trump having difficulty descending ramps and drinking from a glass. The narrator refers to him as "shaky" and "weak" and concludes, "Something's wrong with Donald Trump." Rebecca Cokley, an advocate for disability justice, wrote in a Washington Post op-ed, "the answer to Trump's ableism can't be to outdo him. Ableism hurts people with disabilities regardless of who pushes it."

And, in response to an LP spot titled "Nationalist Geographic," which mocked Trump's appearance and weight, critics like activist Charlotte Clymer pleaded for LP to reconsider their tactics. "I don't like this, Rick [Wilson]. There's so much out there to mock without resorting to body shaming. I could care less about Trump's feelings, but I do care about folks with body types who are already stigmatized and shamed in this way." So, while some lamented the fact that Democrats are seemingly incapable of creating such viscerally aggressive attack ads, others suggested that even if they could make such ads, would they want to? Or should they?

According to stated Lincoln Project strategy, the ends (getting into Trump's head to get him out of office) justify the means (e.g., insulting Trump's physical appearance and sexual stamina). LP member Kurt Bardella contrasts their approach with that of more traditional methods that he considers "less effective." "For years, I have been frustrated with what I perceived to be the Democrats' hesitancy to take the fight to Trump and his Republican accomplices. Former First Lady Michelle Obama's famous catchphrase, 'When they go low, we go high,' makes for stirring oratory, but is not a recipe for defeating the cancer that is Trump." According to LP's Reed Galen, Trump's opponents must be willing to adopt the same strategies as Trump himself, regardless of how distasteful they may seem: "What we found is that you had to be willing and able to take the fight to him the way he would fight with you." LP's Bardella explains it in terms of the inutility of policy-based attacks: "The most effective case against President Trump is using his own words and actions against him. ... People try to make intellectual, policy arguments against him. But this is someone who we feel is a mental midget. And so, that's not going to work. What's going to work is getting inside his head."

Recall that according to the 2019 manifesto from LP founders, the stated goal of LP is to "persuade disaffected conservatives, Republicans and Republican-leaning independents," or, as clarified by LP's Reed Galen to MSNBC, "Republican...mostly white voters, mostly suburban voters." However, they also admit to producing spots aimed at what they call their "audience of one," the president himself. As one Washington Post headline put it, LP wants to "...drive Trump out of office by driving him nuts." LP's John Weaver told National Public Radio's Ari Shapiro, "when we were able to buy time in Washington on one of the president's favorite propaganda shows on Fox, he reacts to it ... and that gives the Biden campaign clean air and time to run their own campaign and run positive messages about the vice president." Regardless of whether LP's ads are designed to persuade disaffected Republicans or to "get in Trump's head" (or both), it is clear that they have adopted a rhetorical strategy and messaging aesthetic that contrast sharply with those of traditional Democratic ads and with progressive values.

\section{Political Psychology and Aesthetics of Political Ideology}

I propose that the differences in the ads produced by the Lincoln Project and those typically produced by liberal and Democratic organizations can be explained in terms of distinct ideological content and themes, as well as distinct "aesthetics of political ideology." Here I borrow the term aesthetics from the philosophy of art, to describe styles of messaging that reflect different artistic and rhetorical principles and values. Palmer, Schloss, and Sammartino (2013) describe aesthetics as "the study of those mental processes that underlie disinterested evaluative experiences" that are anchored at the positive end by feelings that would accompany verbal expressions such as "oh wow! That's wonderful! I love it" and at the negative end by "Oh yuck! That's awful! I hate it!" My research suggests that the aesthetic preferences (and inclinations) of liberals and conservatives in the context of political information can be explained in part by political psychology.

In my book, Irony and Outrage: The Polarized Landscape of Rage, Fear, and Laughter in the U.S., I use a political psychological framework to explain why liberals are more likely to create and appreciate ironic, layered, political satire while conservatives are more likely to create and appreciate 
threat-oriented, hyperbolic political talk. Painting with a broad brush, the psychology of social and cultural political ideology can be explained in terms of the salience of (and orientation to) threat in one's environment. According to this framework, our psychological traits, such as tolerance for ambiguity and need for cognition, result from the way we think about threat. Those who are primed to monitor for threats tend to prefer order and predictability in their environments. They reject the ambiguous and the uncertain. These individuals also tend to have a more acute disgust response, which likely contributes to their physiological aversion to the unfamiliar. When it comes to processing and responding to information, these individuals prioritize efficiency, and capitalize on emotions and cognitive shortcuts.

Meanwhile, those who are less concerned about threats in their environments do not share this need for predictability and order. These people tend to be more open to novel and uncertain experiences. Without salient concerns about threats, efficiency in information processing or decision-making is not as important. Hence, they also exhibit a greater enjoyment of thinking for the sake of thinking and working on solutions to complex problems.

Because of the way these traits shape our engagement with various aspects of the world around us, the political implications are profound. Those who prefer order and predictability are more wedded to tradition, rituals, and to long-standing political and social institutions, hierarchies, and norms. Their threat-monitoring inclinations also make them more conservative on issues of crime and immigration and more hawkish on military matters. These are our social and cultural conservatives. Meanwhile, those who appreciate novelty and the unfamiliar, are less concerned with traditions, and instead are likely to question those same long-standing political and social institutions, hierarchies, and norms. They are more likely to embrace social and cultural change, and even push for it. These folks also lack the threat-monitoring tendency that contributes to concerns about crime, immigration, and national security. Hence, these are our social and cultural liberals.

As it happens, these same traits (tolerance for ambiguity and need for cognition) that help shape our political beliefs are closely tied to artistic preferences as well. Research has found that tolerance for ambiguity and need for cognition (which are higher among social and cultural liberals) predict a greater appreciation for abstract art and stories without a clear plot resolution at the end. Additional studies have confirmed that these traits help to explain why conservatives report greater appreciation for realistic over abstract art and for stories that "wrap things up" at the end versus those that leave the story open to audience interpretation.

Given these psychological tendencies of liberals and conservatives and how they shape preferences for aesthetic forms in the realm of art, it was not all that surprising when I found that these traits correlate with (and help explain) conservatives' lower appreciation for ironic humor. Nuanced, layered messaging that requires cognitive work from the audience to invert its valence and understand its intended meaning will not be a preferred mode of discourse among those who value efficiency and clarity over ambiguity and complexity. Instead, these conservative audiences prefer genres that are clear, emotional, and efficient in their presentation of threats - best described by Outrage Industry authors Jeffrey Berry and Sarah Sobieraj as "outrage programming," such as political talk radio or Fox news "analysis" shows, for example. Illustrative of this underlying psychological mechanism is my finding that exposure to ironic political satire like "The Daily Show" was highest among liberals who scored highest in tolerance for ambiguity. In contrast, exposure to political shock jock Rush Limbaugh was highest among conservatives who scored lowest in tolerance for ambiguity.

In sum, conservatives' high need for closure and penchant for efficient, emotional, heuristic judgments help explain their preference for political opinion talk shows which are threatoriented, hyperbolic, and didactic (like Rush Limbaugh or Sean Hannity). I would argue this is the same reason why the Lincoln Project's team of conservative (former) Republicans is uniquely positioned to create ads that are threat-oriented, hyperbolic, and didactic - and why some on the left find them unappealing and even distasteful.

\section{The Lincoln Project and the Conservative Aesthetic}

The most salient theme across Lincoln Project's ads, and the theme that is most obviously illustrative of a conservative psychological profile, is the theme of threat. From the dark visuals employing high-contrast black-and-white footage with alarming red text, to the ominous music, to the chilling deep voice of the narrator warning of terrible things to come, LP's main messaging ingredient is threat. Asking whether "there will even be an America" if Trump is reelected;" depicting America's growing COVID death rate on a steeply climbing graph with urgent, frightening music that comes to a crescendo as a narrator stresses, "130,000 Americans are dead, 3 million Americans are sick, and thousands more infected every day...;" or the menacing deep voice of a narrator who repeatedly warns "This is how it starts..." followed by descriptions of "shadowy men...snatching so called enemies of the state off the streets," "with no warning or warrant...shoving people in unmarked vans." "Faceless enforcers" who are coming to "YOUR TOWN. YOUR NEIGHBORHOOD."

Threat indeed.

For social and cultural conservatives who are more prone to monitor their environment for threats, such emotionally evocative appeals would seem a natural fit. And the priming of fear and threat complements another theme of LP's messaging, 
military strength and the language of battle and war. In the content of LP's ads - and in interviews with the team - we find an emphasis on military strength and Trump's betrayal of American troops. In "Betrayed," former Navy SEAL Dan Barkhuff criticizes Trump ignoring the reports that Russia was paying Taliban fighters bounties for American deaths in Afghanistan: "I'm a pro-life, gun-owning, combat veteran and I can see Donald Trump for what he is: a coward." In "Bounty," against a soundtrack of military drums and images of flag-draped caskets, a narrator tells the viewer, "When Trump tells you he stands by the troops, he's right, just not our troops."

This military focus extends to the language LP members use in interviews and Op-Eds when describing the team's organizational strategy. "Look, this battle was not something we chose," explained founding member John Weaver, "It kind of came to us. We felt we had no choice but to enter it. I mean, we're in a battle for the hearts and minds of the American people, and we have to take that kind of approach." In an Op-ed in USA Today, LP's Bardella wrote, "The Lincoln Project has become the tip of the spear in the battle to repel Trumpism and wipe out those who have cravenly enabled his tyranny." In a Baltimore Sun article the next day, Bardella quoted a line from The Art of War. Wilson, meanwhile, describes their attacks of President Trump as "psychological warfare." "This guy shows you his throat all the time in this battle," he told Kara Swisher in New York Magazine. On MSNBC's "Into America," Reed Galen described the operations of LP in terms of battle strategy, "Because once we see the attack, like, we go for it, right? There's not a lot of thinking about it. If we believe it's a clean shot, a hard hit, we take it and we take it as quickly as we can."

This wartime language is consistent with LP's focus on physical strength and masculinity. Such themes come through in the negative ads depicting Trump as "shaky," "weak," and having "trouble holding a glass of water." They also are prominent in the positive ads the team has produced for Senate and Congressional candidates. Montana Governor Steve Bullock, running for a U. S. Senate seat, gets a cowboy-themed ad with aerial shots of bison and wild horses, and a tagline of "Montana Strong." Alaskan Senate candidate Al Gross is lauded as "a big character for a big state. Even took down a grizzly when it surprised him... bought a boat at 14 ... and sure as hell isn't a politician." Even humble immunologist and head of the National Institute of Allergy and Infectious Diseases, Dr. Anthony Fauci, gets the toughguy endorsement from the Lincoln Project, with a male narrator describing him as “... an American hero. A kid from Brooklyn who grew up over his family's pharmacy. At 5'7', he was captain of his high school basketball team, a natural leader. Under six presidents he's quietly worked to keep America safe. In a time when truth is under assault, he's always been straight with us."
Perhaps most primal in their integration of masculinity and strength are the ads that equate strength with male sexual prowess. In one ad, a female narrator insults the size of Trump's crowd at his Tulsa rally and taunts, "You've probably heard this before, but it was smaller than we expected. It sure wasn't as big as you promised." In another, the Attenborough-esque narrator describes Trump as the "rare, small-pawed Impotus Americanus" and laments, "Though once considered an Alpha predator, this elderly specimen now weighs somewhat over 300 pounds." And the words used by the ads' creators underscore these gendered themes of masculinity as strength and femininity as weakness. In an appearance on the Late Show, LP's Wilson referred to Trump as a "whining bitch addicted to Twitter." Earlier in June, LP video editor Ben Howe was kicked off the team for social media posts that used female body parts as insults, including "vagina," "c-nt," or "twat." As political scientist Kelly Dittmar explained in Glamour Magazine,

If the playbook for over 100 years has been for a presidential candidate to prove he's man enough for the job and therefore emasculate his opponents, the battle is over masculinity," she says. "Your engaging in a strategy of emasculation only reinforces masculine dominance and doesn't envision a world or a presidency in which you could value other traits or areas of expertise as important.

Just as political psychology can help explain conservative LP members' preeminent focus on threat and language of war, so too does it help explain the relationship between genderrelated beliefs and political ideology. Individuals with lower ambiguity tolerance hold more stereotypical beliefs about gender roles and expectations. Threat-monitoring fuels a need for certainty, predictability, and clarity - in concepts and in social roles. Need for closure (or lack of ambiguity tolerance) would therefore contribute to these more gendered expressions of leadership, strength, and power. And so it does in the Lincoln Project ads.

Which brings us to the LP strategies of mockery and hyperbole. While most LP ads are negative, ominous attack ads, some of the most widely circulated spots are those that taunt and mock the president. In one of the most widely shared of LP's ads, "Trumpfeld," the producers simply overlaid a sitcom laugh-track over President Trump's July interview with Fox's Chris Wallace, leaving the viewer with the palpable impression that Trump is a laughable buffoon and everyone knows it. Referring to Trump having boasted about a "cognitive test" he aced, the narrator concludes, "Don't you believe America deserves a President who doesn't brag that he can spot an elephant?" Placing a laugh track over the president may be the most overtly mocking of LP's tactics, but they also routinely use hyperbole as a form of insult and derision. 
Hyperbole makes use of exaggeration and overstatement to make an evaluative observation or argument - not by inverting a statement's valence as is done in irony, but by heightening the intended valence to the point of the absurd. Whereas linguistic and neuropsychological research indicates that comprehension of complex ironic messages is cognitively taxing and requires multiple processing steps, hyperbole does not. As such, it is a preferred form for those inclined towards efficiency and clarity (read: social and cultural conservatives). The hyperbolic statement describes as deadly that which is bad and fantastic that which is good. Calling Trump "Comrade Trump" to suggest he is coordinating with the Russians; referring to Trump as a "weak, unfit, shaky President," his campaign as a "billion dollar criminal enterprise," and his son-in-law Jared Kushner as "Secretary of Failure." These rhetorical devices are designed to efficiently attack the President and his administration in emotionally evocative ways, leaving viewers with an unmistakable sense of the messages' meaning. Such tactics are emblematic of the conservative rhetorical aesthetics of simplicity and efficiency.

While hyperbole exaggerates the evaluative scale of a statement to make its argument abundantly clear, irony does the opposite. Irony inverts the literal valence, requiring that the audience recognize the need to flip the evaluation upside down. I contend that this multi-step process, combined with the inherent ambiguity of a text that says the opposite of what it means, operate counter to the needs and aesthetic preferences of conservatives, who possess lower tolerance for ambiguity and lower need for cognition. My experimental work suggests that need for cognition in particular helps explain conservatives' lower appreciation for irony compared to their liberal counterparts.

Importantly, there is one LP ad that has hints of irony: the July 30 spot, "Wake Up," which at the writing of this piece is the most viewed of the Lincoln Project ads (with 3.4 million views). And, while this darkly humorous take on Trump's years in office has some suggestions of irony (by describing as good those things that are obviously bad), the end of the ad places it firmly in the land of hyperbole once again. The ad features a young man who has just awoken from a 3.5 year coma, being greeted by his family who fills him in on "what he's missed." They delightfully reminisce about the Republican Presidential victory in 2016. "He's keeping the Mexicans out!" says the dad. The mom expresses support for protests against police brutality because, as she says with incredulity, “... the police keep accidentally killin' black people!" When the son suggests that the news networks must be "just destroying" Trump over the reports that Russians had placed a bounty on U.S. soldiers' heads in Afghanistan, his sister laughs dismissively, "We don't listen to [the news] - or the scientists! It's Fake News!" they chant, "Fake News! Fake News!" Until this point, the ad illustrates a more liberal aesthetic, inviting the audience to reconsider whether these features being celebrated are actually good, and thereby relying on the audience to make the cognitive and evaluative leap to say "no, they are not good. They are bad." Typically, in ironic satire, this is where the (usually liberal) satirist would leave us, inviting us to make the argument ourselves. But not the Lincoln Project. As the man's family gets distracted talking about the economic downturn and how the dad has lost his job, we watch as the son in the hospital bed reaches up and unplugs his own life support. The on-screen text reads: "Republicans ... we need to wake up." But the more obvious message is: This young man would rather be dead than live in Trump's America. For the conservative Lincoln Project team, hyperbole wins again.

\section{Closing}

In the 2020 Presidential campaign season, the conservative Lincoln Project has capitalized on the largely unregulated land of American campaign finance to create an efficient, social media-driven ad machine. In tenor, content, and aesthetic, the ads of the GOP-led anti-Trump super PAC are distinct from those typically produced by Democratic campaigns. With dark, ominous warnings of threats to come, hyperbolic appeals and insults, and ad hominem attacks on Trump's masculinity and lack of physical strength, the strategy of the Lincoln Project illustrates how social and cultural conservatives' psychological traits lead them to prefer particular messaging aesthetics. With high need for closure, and processing goals driven by efficiency, conservatives would likely be receptive to such threat-oriented, didactic, hyperbolic, and efficient political messaging. Whether a reflection of the psychological inclinations of the conservatives who create the ads, or of their keen understanding of the psychology of their conservative and Republican-leaning target audience, there is reason to believe that LP's ads will resonate with the needs and preferences of a conservative audience, serving to reify this link between psychology and politics once again.

For the past half-century, Americans' political identities have become increasingly linked to their social, cultural, and racial identities. Political strategists and propagandists have learned to make use of these salient (and primal) group identities to help create and disseminate messages carrying preferred themes and content through a preferred messaging aesthetic. And social media's microtargeting capabilities make all this possible. LP's Wilson described "the hellscape that is Facebook" as "...the most meaningful tool of political manipulation ever devised in the history of all mankind." He continued,

It has a suite of tools that allows you to segment and target your audience in ways that are enormously granular. You can voter-file match people. You can now go out and match the cable and the Rentrak data to a lot of 
the Facebook data that's available, and it lets you silo a person, not a demographic group. With cable, I can get you down into your neighborhood and your household somewhat. With Facebook, I can make sure that the ads following you on your phone and on your computer and on your tablet are all telling you that unless you vote for Donald Trump, antifa is coming to kill your dog.

The Lincoln Project illustrates the next iteration of messagematching in strategic political communication: matching message content, style, and packaging to the political, social, cultural, and psychological predispositions of individuals to maximize emotional responses and mobilization. To do this requires a mastery of both the psychology of your target audience and the tools at your disposal.

So, the reason that Democratic strategists haven't made these same visceral attack ads against Trump?

It's not because they don't have the same targeting toolbox.

It's because they're not Republicans.

\section{Further Reading}

Berry, J. M., \& Sobieraj, S. 2013. The outrage industry: Political opinion media and the new incivility. Oxford University Press, Oxford.

Feist, G. J., \& Brady, T. R. 2004. 'Openness to experience, non-conformity, and the preference for abstract art.' Empirical Studies of the Arts, 22(1): 77-89.
Hetherington, M., \& Weiler, J. 2018. Prius Or Pickup?: How the Answers to Four Simple Questions Explain America's Great Divide. Houghton Mifflin, Boston.

Hibbing, J. R., Smith, K. B., \& Alford, J. R. 2013. Predisposed: Liberals, conservatives, and the biology of political differences. Routledge, Abingdon.

Jost, J. T., Glaser, J., Kruglanski, A. W., \& Sulloway, F. J. 2003. 'Political conservatism as motivated social cognition.' Psychological bulletin, 129(3): 339.

Mason, L. 2018. Uncivil agreement: How politics became our identity. University of Chicago Press.

Palmer, S. E., Schloss, K. B., \& Sammartino, J. 2013. 'Visual aesthetics and human preference. Annual review of psychology' 64: 77-107.

Wiersema, D. V., Van Der Schalk, J., \& van Kleef, G. A. 2012. 'Who's afraid of red, yellow, and blue? Need for cognitive closure predicts aesthetic preferences.' Psychology of Aesthetics, Creativity, and the Arts, 6(2): 168.

Wilson, G. D., Ausman, J., \& Mathews, T. R. 1973. 'Conservatism and art preferences.' Journal of Personality and Social Psychology, 25(2): 286

Young, D. G. 2019. Irony and outrage: The polarized landscape of rage, fear, and laughter in the United States. Oxford University Press, New York.

Young, D. G., Bagozzi, B. E., Goldring, A., Poulsen, S., \& Drouin, E. 2019. 'Psychology, political ideology, and humor appreciation: Why is satire so liberal?' Psychology of Popular Media Culture, 8(2): 134.

Publisher's Note Springer Nature remains neutral with regard to jurisdictional claims in published maps and institutional affiliations.

Dannagal G. Young is a professor of communication at the University of Delaware. Her new book, Irony and Outrage: The Polarized Landscape of Rage, Fear, and Laughter in the United States, was published by Oxford University Press last December. 